\title{
LOJALNOST, GLAS ILI IZLAZAK: IZBORNA PARTICIPACIJA I POTPORA NOVIM STRANKAMA U HRVATSKOJ
}

\author{
Andrija Henjak \\ Fakultet političkih znanosti \\ Sveučilišta u Zagrebu \\ E-mail: andrija.henjak@fpzg.hr
}

\author{
DOI: $10.20901 / a n .14 .04$ \\ Izvorni znanstveni rad \\ Prihvaćeno: siječanj 2018.
}

\begin{abstract}
Sažetak Autor analizira promjene izborne participacije i izbornog ponašanja u parlamentarnim izborima 2015. i 2016. u Hrvatskoj, kada su podrška novim strankama i izborna apstinencija dosegnuli najvišu razinu od 1990. Polazi od pretpostavke da birači novih stranaka i izborni apstinenti imaju sličan odnos prema političkom sustavu i elitama, ali da ih razlikuje percepcija vlastite mogućnosti utjecaja na politiku. Istodobno, birači novih i starih stranka slični su prema percepciji vlastitih mogućnosti utjecaja na politiku, ali se razlikuju odnosom prema prevladavajućima političkim rascjepima, političkom sustavu i političkim elitama. Autor testira te pretpostavke koristeći rezultate anketnih istraživanja koja su provedena neposredno nakon izbora 2015. i 2016. Rezultati analize potvrđuju očekivanja o razlikama među biračima starih i novih stranaka te izbornih apstinenata.
\end{abstract}

Ključne riječi izborna participacija, izborno ponašanje, politički rascjepi, stranačko natjecanje, politička efikasnost

\section{Uvod}

Posljednjih nekoliko ciklusa izbora u Hrvatskoj obilježila su dva gotovo usporedna trenda: postupno smanjivanje broja birača $u$ nacionalnim izborima i povećanje broja birača koji su glasovali za stranke nastale nakon 2000. te stoga nemaju organizacijske i kadrovske korijene u ranima devedesetim godinama kada je nastajao hrvatski stranački sustav. Pad izborne participacije i osjetan porast podrške novim strankama pokazuju da je znatan broj birača ostao izvan strukture političkih rascjepa utemeljenih na identitetskima, vrijednosnim i ideološkim polarizacijama koje dijele ljevicu i desnicu u Hrvatskoj, te da stranački sustav uspostavljen devedesetih godina više nije sposoban reprezentirati velik broj birača koji se stoga pasiviziraju ili traže nove opcije u izborima (Bagić 2007; Zakošek 1998, 2001; Čular i Grgurić, 2007; Šiber 1997, 1998, 2001, 2003; Zakošek i Čular 2004; Henjak, Zakošek i Čular 2013; Ferić, 2008; Henjak 2011).

Izborna apstinencija i potpora novim strankama različiti su oblici političkog 
ponašanja koji imaju drugačije posljedice za demokraciju i funkcioniranje političkog sustava. Primijeni li se Hirschmanovo $\left(2010,1970^{1}\right)$ shvaćanje na hrvatski kontekst, potpora etabliranoj ljevici i desnici izražava lojalnost strankama nastalima odmah nakon 1990. i političkim identitetima koje one predstavljaju, glas za nove stranke izražava prosvjed protiv statusa quo u stranačkom sustavu i traženje novih aktera koji bi bolje predstavljali preferencije birača, a izborna apstinencija izražava izlazak iz politike i odustajanje od sudjelovanja u izborima koji su temeljni demokratski mehanizam koji osigurava predstavljenost građana $\mathrm{u}$ procesima političkog odlučivanja.

Glas za nove stranke i izlazak iz političke arene $\mathrm{u}$ demokraciji podrazumijevaju bitno drugačiji odnos prema politici te, u osnovi, razlikuju aktivne od pasivnih građana. Birači koji glasuju za nove stranke pokazuju da još vjeruju u to da se izborima može utjecati na političke odluke i smatrati političke aktere odgovornima za rezultate tih odluka. Građani koji ne sudjeluju u izborima ne mogu osigurati zastupljenost svojih interesa i vrijednosti u parlamentu, kao što ne mogu političke elite smijeniti na izborima ako nisu zadovoljni njihovim radom i glasovati za druge aktere. Izuzmemo li građane koje politika uopće ne zanima, neizlazak na izbore ukazuje na nedostatak vjere građana u vlastitu mogućnost utjecaja na političke procese i odluke koje donose političke elite (Jung 2016; Grönlund i Setälä 2007). Izborna apstinencija pokazuje i to da dio građana ne doživljava političke stranke kao organizacije koje predstavljaju njihove vrijednosti, interese ili političke identitete (Streeck i Merterns 2013).

Smanjenje izborne participacije i povećanje potpore novim strankama u posljednjem desetljeću u Hrvatskoj upućuju na slabljenje identifikacije bi- rača sa strankama lijevoga i desnog bloka te smanjenje njihova mobilizacijskog potencijala. Ti trendovi ukazuju i na slabljenje važnosti identitetskih i ideoloških rascjepa koji su dominirali hrvatskom politikom. Promjene u izbornoj participaciji i biračkom ponašanju utječu na hrvatski politički sustav, a posebno na stranački sustav i obrazac političkog natjecanja, te ih čine vrijednima istraživanja. Stoga u ovom radu nastojim utvrditi uzroke izborne apstinencije i potpore novim strankama u Hrvatskoj u parlamentarnim izborima 2015. i 2016. u kojima su i izborna apstinencija i potpora novim strankama dosegnule najvišu razinu.

S obzirom na usporednost tih trendova, a i zbog potpunijeg razumijevanja čimbenika koji utječu na potporu novim strankama i izbornu apstinenciju, ta dva trenda treba promatrati kao lice i naličje jedne pojave, koja pokazuje promjenu odnosa sve većeg broja građana prema politici, etabliranim strankama i političkim rascjepima koje one predstavljaju. Usporednim promatranjem tih dvaju trendova može se steći jasnija slika o razlikama između birača novih stranaka i izbornih apstinenata, odnosno o razlikama između građana koji su zapravo odustali od politike i građana koji još vjeruju da sudjelovanjem u izborima mogu utjecati na političke događaje.

U radu analiziram razlike između birača starih i novih stranaka te izbornih apstinenata, odnosno čimbenike koji su povezani s glasovanjem za stare i nove stranke te s izbornom apstinencijom. $\mathrm{Na}$ temelju anketnih podataka prikupljenih neposredno nakon parlamentarnih izbora 2015. i 2016. pokušavam odgovoriti na pitanje razlikuju li se birači novih stranaka i izborni apstinenti od birača starih stranaka svojim odnosima prema političkim rascjepima, demokraciji, politici, elitama i institucijama, te po svojemu socijalno-ekonomskom statu- 
Slika 1. Kretanje broja birača u parlamentarnim izborima u Hrvatskoj.

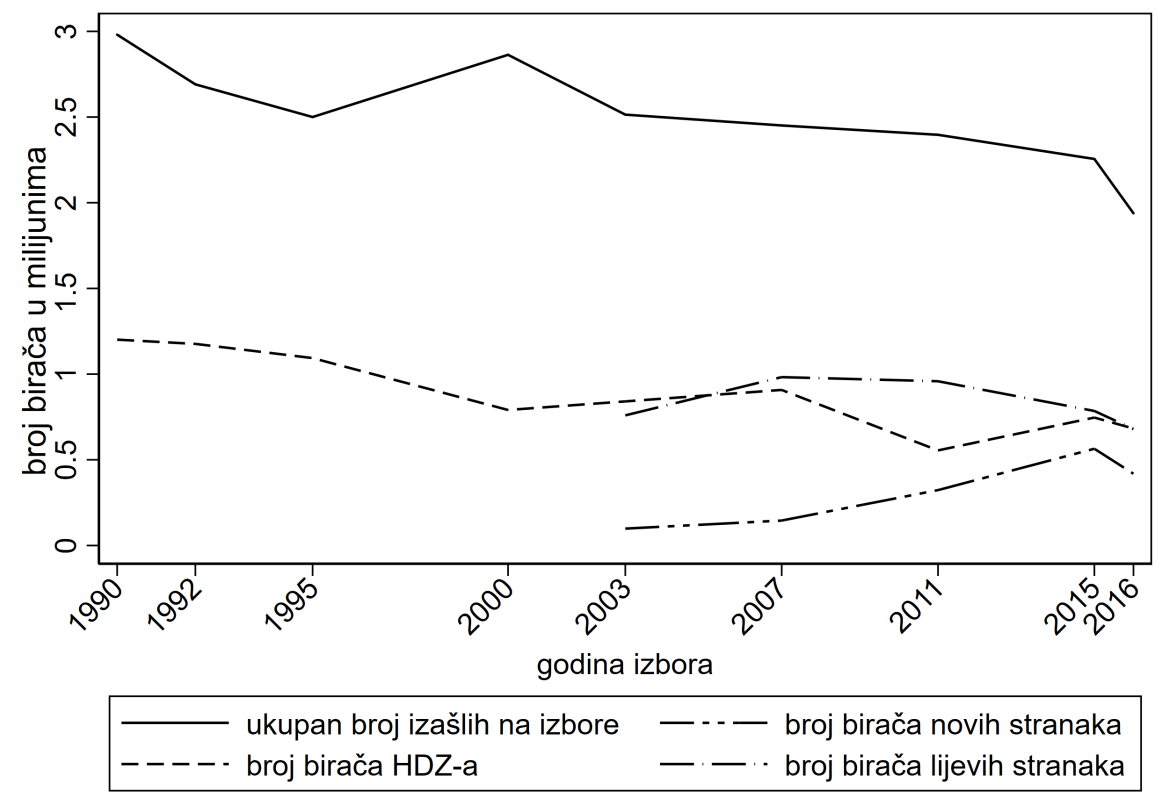

Napomena: u broj birača HDZ-a uračunati su birači njegovih koalicijskih partnera 2015. i 2016, a u broj birača lijevih stranaka birači SDP-a, HNS-a i IDS-a te stranaka koje su bile u koaliciji s njima.

su. Nastojim odgovoriti i na pitanje što uzrokuje da se dio građana politički pasivizira, dok drugi dio nastavlja sudjelovati u politici glasujući za nove stranke.

\section{Trendovi izborne} apstinencije i potpora novim
strankama u Hrvatskoj

Izbornu participaciju u Hrvatskoj od 1990. do 2015. obilježio je postupan pad broja birača koji su sudjelovali u parlamentarnim izborima, osim kritičnih izbora 2000. Najviše birača, gotovo tri milijuna, izašlo je na prve parlamentarne izbore 1990, a samo oko sto tisuća manje na parlamentarne izbore $2000 .{ }^{1}$ Na ostalim izborima, osim izbora 1992. na koje je izašlo malo više od 2,7 milijuna birača, broj birača kretao se od 2,4 do

\footnotetext{
Kako se broj birača u biračkim popisima znatno mijenjao od izbora do izbora, apsolutan broj birača koji su izašli na izbore pouzdaniji je pokazatelj participacije od njihova postotka.
}

2,5 milijuna. Prvi je put broj birača znatnije pao u izborima 2015, u kojima je sudjelovalo oko 2,25 milijuna birača, da bi u izborima 2016. prvi put sudjelovalo manje od dva milijuna birača (slika 1).

Broj birača u izborima smanjivao se usporedno s porastom broja birača novih stranaka, to jest s padom ukupnog broja birača koji su glasovali za stranke lijevoga i desnog bloka nakon izbora 2003. Broj birača koji su glasovali za stranke nastale devedesetih godina $u$ svim je izborima do 2000. bio veći od 2,5 milijuna, dok je u izborima 2003. i 2007. bio neznatno veći od dva milijuna. U izborima 2011. ukupan broj birača koji su glasovali za stranke lijevoga i desnog bloka pao je ispod 1,8 milijuna, u izborima 2015. spustio se na oko 1,6 milijuna, da bi u izborima 2016. pao ispod 1,4 milijuna, što je najniža razina u povijesti suvremenoga hrvatskog parlamentarizma. Istodobno, broj birača novih stranaka - ako ih definiramo 
kao stranke koje nemaju ni organizacijski kontinuitet ni kontinuitet političkih elita od devedesetih godina - postupno se povećavao od 2000. Nove stranke, odnosno stranke koje nisu nastale cijepanjem stranaka koje potječu iz devedesetih godina, osvojile su u izborima 2003. i 2007. manje od 150.000 glasova. U izborima 2011. nove stranke, ponajprije Hrvatski laburisti, lista Ivana Grubišića i Blok umirovljenici zajedno, dobile su više od 250.000 glasova i osam mjesta u parlamentu. No taj rezultat nije promijenio bipolarnu dinamiku stranačkog natjecanja koje se strukturiralo oko rascjepa utemeljenih na povijesti, religiji i tradiciji, dok su se na vlasti smjenjivale stranke lijevoga i desnog bloka.

Tek je u redovnim izborima 2015. i prijevremenim izborima 2016. potpora novim strankama znatnije porasla. Nove stranke, Most, Živi zid, Pametno i Stranka rada i solidarnosti, dobile su više od 400.000 glasova u tima dvama izbornim ciklusima. Istodobno, broj glasova koje su osvojile etablirane stranke ljevice i desnice pao je na najnižu razinu dotad. Važnije od broja glasova bile su promjene u stranačkom sustavu. Izborni rezultati novih stranaka proizveli su odnos snaga u parlamentu u kojemu koaliciju nisu mogle sastaviti samostalno ni stranke lijevoga ni stranke desnog bloka pa su bile prisiljene birati između suradnje s novim strankama, koje su nastale iz prosvjeda protiv etabliranih elita i njihova načina upravljanja državom odnosno protiv samih starih stranaka, i suradnje sa strankama iz suprotnoga ideološkog bloka s kojima ne dijele suglasnost o temeljnim vrijednostima i ideološkim pitanjima. U tom su smislu izbori 2015. i 2016. promijenili obrasce biračkog ponašanja, stranačkog natjecanja i formiranja vlade. ${ }^{2}$ Tek će se pokazati jesu li ti

2 U izborima 2000. promijenjen je obrazac stranačkog natjecanja pa se sustav s dominantnom strankom, koji je prevladavao devedesetih godina, transformirao $u$ izbori donijeli i trajnije smanjenje broja birača koji izlaze na izbore.

\section{Izborna participacija, pojava novih stranaka i promjena stranačkog sustava}

Slični trendovi u izbornoj apstinenciji i promjeni obrazaca biračkog ponašanja zabilježeni su i u drugim zemljama Srednje i Istočne Europe. Analize su potvrdile pad izborne participacije poslije prvih demokratskih izbora u kojima je u svim tim zemljama zabilježena najveća izlaznost. Nakon konstitutivnih izbora izlaznost se smanjivala pa je već u četvrtome izbornom ciklusu bila dvadesetak posto manja nego u prvima parlamentarnim izborima (Kostadinova 2003; Northemore Ball 2016; Pacek, Pop Eleches i Tucker 2009; Linek i Petrušek 2016). Unatoč tome općem trendu, izborna participacija nije se kretala isključivo jednosmjerno. Komparativne analize zemalja Srednje i Istočne Europe pokazale su da se broj birača povećavao na posebno značajnima ili kompetitivnim izborima (Pacek, Pop-Eleches i Tucker 2009).

$\mathrm{Uz}$ smanjenje izborne participacije, drugo i treće desetljeće političkog razvoja u zemljama Srednje i Istočne Europe karakterizirale su izražena nestabilnost stranačkog sustava i pojava novih stranaka (Haughton i Deegan Krause 2015; Tavits 2007; Sikk 2005). Nove stranke pojavile su se uvelike kao reakcija birača na korupciju političkih elita i ekonomske probleme te kao izraz kritike političkog kartela starih stranaka koje su željele

bipolarni stranački sustav koji je od 2000 . do 2015. karakterizirala bipolarna dinamika sa smjenama ljevice i desnice na vlasti. Poslije izbora 2015. lijevi i desni blok nisu više bili sposobni samostalno formirati vladu te su se suočili s izborom između koaliranja s novim strankama ili sa strankama iz drugoga ideološkog bloka, što je druga važna promjena kompetitivne dinamike hrvatskoga stranačkog sustava. 
očuvati politički i ekonomski status quo (Hanely i Sikk 2016). Nove stranke, koje Hanely i Sikk (2016) nazivaju protuestablišmentskima reformskim strankama, novi su akteri na političkoj pozornici, a njihove poruke čini kombinacija kritike političkih elita sa zahtjevima za reformom političkog sustava koja bi povećala izravnu participaciju građana u političkom odlučivanju i učinila političare neposrednije odgovornima građanima (Sikk 2012; Hanley and Sikk 2016). Nove stranke pojavljuju su se u kontekstu koji određuje kombinacija ekonomskih problema, sve veće korupcije i percipirane primarne usmjerenosti političkih elita na održanje na vlasti i kontrole javnih resursa umjesto na provođenje javnih politika usmjerenih na rješavanje ekonomskih problema i efikasno upravljanje (Haughton i Deegan-Krause 2015; Engler 2016; Pop-Eleches 2010).

Stranački sustavi nisu se mijenjali u svim zemljama Srednje i Istočne Europe jednako brzo. Stranački sustavi u kojima natjecanjem dominira jedna ideološka dimenzija pokazali su se otpornijima na pojavu novih stranaka od stranačkih sustava u kojima postoji više ideoloških dimenzija koje strukturiraju stranačko natjecanje (Casal Bertoa 2014; O'Dwyer 2014). Hrvatski stranački sustav, u kojemu dominira jedna ideološka dimenzija natjecanja koja kombinira odnos prema povijesti, religiji i tradiciji te identitetu, tek je u izborima 2015. i 2016. doživio prvu značajniju promjenu. Naime, tada su se pojavile nove stranke s izbornom potporom koja je bila dostatna da se uistinu dovedu u pitanje postojeći model politike i dominacija stranaka lijevoga i desnog bloka političkim sustavom. Iako je hrvatski stranački sustav i prije pokazivao znakove nestabilnosti zbog pojave novih stranaka, dominacija jedne dimenzije natjecanja koja dijeli ljevicu i desnicu te centrifugalna dinamika stranačkog natjecanja ograničile su izborni potencijal novih stranaka i suočile ih $\mathrm{s}$ time da moraju birati između svrstavanja u lijevi ili desni blok ili ostati izvan blokova, što je posljedovalo vrlo malim utjecajem na politiku i, u konačnici, gubitkom izborne potpore (Čular 2013). U izborima 2015. i 2016. ni lijevi ni desni blok nisu uspjeli osvojiti većinu, a nove su stranke postale dovoljno jake da mogu dovesti u pitanje bipolarnu strukturu i centrifugalnu dinamiku stranačkog natjecanja. Pritom su uspjele mobilizirati birače porukama koje dovode u pitanje postojeći model upravljanja zemljom i ulogu političkih stranaka u njemu, postojeći ekonomski model i institucije koje ga podržavaju te raspodjelu ekonomske moći u društvu.

U tom se sklopu smanjenje izborne participacije i povećanje potpore novim strankama usmjerenima na kritiku političkog sustava mogu promatrati kao izrazi nezadovoljstva strankama koje su dominirale hrvatskom politikom u posttranzicijskom razdoblju. Ako je ta pretpostavka točna, odnosno ako su izborna apstinencija i glasovanje za nove stranke izrazi nezadovoljstva starim strankama, nameće se pitanje što razlikuje birače novih stranaka i apstinente, kao i pitanje što ih zajedno razlikuje od birača etabliranih stranaka.

Nastanak nove dimenzije natjecanja u Hrvatskoj znači da se znatan segment birača ne identificira s tradicionalnima povijesnim i identitetskim rascjepima te da se mobilizira oko političkih pitanja koja su neovisna o njima. Pritom je posve moguće da birače starih i novih stranaka razlikuje ponajprije odnos prema političkim elitama i nezadovoljstvo funkcioniranjem političkoga i ekonomskog sustava, što novu dimenziju natjecanja koja dijeli birače starih i novih stranaka može učiniti privremenom. Nadalje, kako izborna apstinencija i politička pasivizacija u širem smislu mogu biti odgovori na nezadovoljstvo 
političkim elitama i načinom djelovanja političkog sustava, potrebno je utvrditi je li uistinu riječ o novoj dimenziji političkog natjecanja koja se temelji na odnosima prema konkretnim pitanjima, te jesu li razlike između birača novih stranaka i izbornih apstinenata dublje jesu li zasnovane na neadekvatnoj političkoj reprezentaciji potonjih ili su rezultat odustajanja od politike i percepcije da se političkom participacijom ne može mnogo promijeniti.

\section{Glas ili izlazak: odrednice biračkog ponašanja na individualnoj razini}

Konkretni uzroci tih pojava razlikuju se od zemlje do zemlje i od stranke do stranke. No može se pretpostaviti da birači ostaju lojalni starim strankama zbog identifikacije s njima is političkim identitetima ili društvenim skupinama koje one predstavljaju. Osim toga, ti birači vjerojatno ne doživljavaju političke elite i njihove javne politike kao problem ili ih makar ne doživljavaju kao takav problem da im se potpora starim strankama čini neprihvatljivom opcijom. Nadalje, birači koji ostaju lojalni starim strankama obično su stariji od birača novih stranaka i zacijelo su razvili politički identitet i stranačku identifikaciju na temelju političkih rascjepa koji su dominirali razdobljem prije političke tranzicije i neposredno poslije nje (Karp i Banducci 2008; Czesnik, Zerkowska-Balas i Kotnarowski 2013; Jung 2017; Grönlund i Setälä 2007).

Birači novih stranaka vrlo se vjerojatno manje identificiraju s postojećima političkim identitetima, strankama ili rascjepima, što može značiti da su manje ideološki i vrijednosno polarizirani te da pripadaju mlađim generacijama koje su se politički socijalizirale nakon demokratske tranzicije, to jest u razdoblju u kojemu demokracija više nije bila upitna i u kojemu su dominirala pi- tanja vezana za ponašanje političkih elita, kvalitetu demokracije i funkcioniranje ekonomskog sustava uspostavljenog nakon tranzicije. Nasuprot izbornim apstinentima, ti birači vjerojatno nisu ni politički ni ekonomski isključeni. Iako ne vjeruju političkim elitama i nisu zadovoljni demokracijom, ipak nisu apatični i vjeruju da politička participacija nije izgubila smisao te da se na političke događaje može utjecati (Karp i Banducci 2008; Czesnik, Zerkowska-Balas i Kotnarowski 2013).

Komparativne studije odrednica potpore novim strankama na individualnoj razini u zemljama Srednje i Istočne Europe relativno su rijetke, ali iz onih koje postoje može se razabrati da birači novih stranaka nemaju izraženu stranačku identifikaciju, da misle kako nije važno tko je na vlasti i da su nezadovoljni načinom funkcioniranja demokracije (Pop-Eleches 2010). Niska razina stranačke identifikacije izražava se tako što birači novih stranaka lako mijenjaju svoje preferencije i glasuju za nove stranke ako nisu zadovoljni efikasnošću stranaka za koje su glasovali na prethodnim izborima (Haughton i Deegan-Krause 2015). Nadalje, studije utjecaja korupcije na biračko ponašanje u zemljama Srednje i Istoče Europe pokazuju da su birači smješteni u ideološkom centru i birači koji nemaju jaku stranačku ili ideološku identifikaciju skloniji glasovati za nove stranke kada su suočeni s rastućom korupcijom političkih elita nasuprot biračima koji su ideološki udaljeni od centra i koji imaju izraženu stranačku identifikaciju (Charron \& Bagenholm 2016; Ecker i dr. 2016). Taj je učinak izraženiji kod birača koji vjeruju da se izborima može utjecati na političke događaje i koji smatraju da su političke elite odgovorne za ishode politika (Ecker i dr. 2016).

Izborni apstinenti dijele s biračima novih stranaka odnos prema politici i po- 
litičkim elitama (Jung 2017; Grönlund i Setälä 2007; Czesnik, Zerkowska-Balas i Kotnarowski 2013). No među njima postoji i važna razlika: birači koji izlaze na izbore općenito su politički informiraniji, socijalno uključeniji, imaju veće povjerenje i interes za politiku te izraženiji osjećaj da mogu utjecati na političke događaje od onih koji ne izlaze na izbore (Karp i Banducci 2008; Jung 2017; Grönlund i Setälä 2007; Czesnik, Zerkowska-Balas i Kotnarowski 2013; Goerres 2007). Razlika između apstinenata i birača novih stranaka očituje se i u usporedbi birača radikalnih stranaka $i$ izbornih apstinenata: biračima radikalnih stranaka i apstinentima zajedničko je nepovjerenje $u$ etablirane stranke $i$ političare, ali su birači radikalnih stranaka sličniji ostalim biračima prema razinama povjerenja u druge ljude i prema uključenosti u društvene aktivnosti i rad društvenih organizacija (Allen 2017).

Izborni apstinenti čine skupinu koju uz nedostatak povjerenja u političke aktere i institucije, nepostojanje stranačke identifikacije i nezadovoljstvo funkcioniranjem demokracije - karakteriziraju nedostatak interesa za politiku, slaba politička informiranost i uvjerenje da se izbornom participacijom ne može utjecati na političke procese. Izborna apstinencija i slaba uključenost u politiku općenito su povezane i s niskim razinama povjerenja u druge ljude i uključenosti u društvene aktivnosti i rad društvenih organizacija (Letki 2004; Allen 2017; Jensen i Jaspersen 2017).

Komparativne studije, nadalje, pokazuju da je vjerojatnost izborne i političke participacije općenito uvelike povezana sa stupnjem obrazovanja građana, pri čemu su obrazovaniji građani skloniji sudjelovati u izborima (Goerres 2007; Letki 2004; Gallego 2010; Allen 2017; Schäfer 2013). Obrazovaniji su građani politički sofisticiraniji i uključeniji u politiku, što samo po sebi utječe na njihovu volju da se politički angažiraju. Obrazovaniji građani imaju i viši socijalno-ekonomski status, što povećava važnost političke participacije kao mehanizma utjecaja na politiku i zaštite vlastitoga ekonomskog statusa i pravâ. Slabije obrazovani građani politički su nesofisticiraniji i nezainteresiraniji za politiku te, u sklopu ekonomske politike koja je uvelike depolitizirana i koju kontroliraju transnacionalne organizacije, ne osjećaju da sudjelovanjem u izborima mogu utjecati na javne politike i poboljšati svoj ekonomski položaj (Schäfer 2013; Offe 2013).

Izborna participacija izrazito je povezana i s generacijskom pripadnošću i životnom dobi. Niz studija potvrđuje kako je vjerojatnije da će stariji birači sudjelovati u politici, napose u izborima (Goerres 2007; Letki 2004; Gallego 2010; Grasso 2014; Schäfer 2013; Linek i Petrušek 2016; Pop-Eleches i Tucker 2013; Northmore-Ball 2016; Jung 2017; Czesnik, Zerkowska-Balas i Kotnarowski 2013). Te studije potvrđuju da obrazovanje i socijalno-ekonomski status starijih građana znatno manje utječu na vjerojatnost glasovanja, odnosno da su znatno manje razlike u vjerojatnosti sudjelovanja u izborima među različitima obrazovnim i dohodovnim skupinama starijih građana. Veća participacija starijih građana povezana je s duljim vremenom u kojemu su mogli oblikovati obrazac političkog ponašanja i internalizirati političku participaciju kao normativno poželjan oblik djelovanja, posebno u sklopu tranzicije tijekom koje su slobodni izbori i demokracija zamijenili autokratski sustav u kojemu nije bilo slobodnih izbora. Razlika u participaciji povezana je i s generacijskom pripadnošću, to jest s različitim iskustvima političke socijalizacije pojedinih naraštaja, što proizvodi različite obrasce ponašanja, odnosno različite vrste motiva za sudjelovanje u izborima: primjerice, sta- 
riji birači koji su živjeli dulje u autokratskim režimima skloniji su gledati na demokraciju i izbore kao na vrijednosti po sebi nasuprot mlađim biračima koji nemaju takvo iskustvo i koji demokraciju vrednuju isključivo prema rezultatima koje proizvodi.

Osim obrazovanja i dobi, važna je odrednica izborne participacije i socijalno-ekonomski status. Manje je vjerojatno da će u izborima sudjelovati nezaposleni, slabije plaćeni i zaposleni na poslovima koji su izloženiji socijalnim rizicima (Jensen i Jespersen 2017; Schäfer 2013; Letki 2004). Povezanost izborne apstinencije i nižega socijalnog i ekonomskog statusa bivala je sve izraženija s protokom vremena. Pritom se razlike u participaciji različitih socijalno-ekonomskih skupina povećavaju usporedno s porastom nejednakosti i slabljenjem organizacija, kakvi su sindikati, koje mogu mobilizirati radnike, kao i s reduciranjem socijalne države, pri čemu su razlike među socijalno-ekonomskim skupinama izraženije u zemljama $s$ višom razinom nejednakosti (Schäfer 2013; Streeck i Merterns 2013; Jensen i Jespersen 2017; Northermore-Ball 2016; Anderson i Beramandi 2012). Neki autori povezuju slabiju izbornu participaciju nižih socijalno-ekonomskih skupina i s približavanjem ekonomskih pozicija stranaka i depolitizacijom ekonomske politike, što potiče političku pasivizaciju građana nižega socijalno-ekonomskog statusa zato što političke stranke više ne predstavljaju njihove interese, a ekonomska politika više ne zadovoljava njihove potrebe (Offe 2013). Komparative studije povezanosti izlaznosti na izbore i redistribucije, odnosno razine dohodovne nejednakosti, pokazale su da je viša izlaznost na izbore povezana $\mathrm{s}$ višom razinom redistribucije i dohodovne jednakosti. To ukazuje na povratnu spregu između izborne participacije i snage socijalne države: participacija nižih socijalno-ekonomskih skupina osigurava političku podršku socijalnoj državi, a razvijenija socijalna država djeluje kao motiv za izbornu participaciju tih skupina (Larcinese 2007; Schäfer 2013; Mahler, Jesuit i Paradowski 2015).

Veći broj studija pokazuje da je članstvo u sindikatima posebno važna varijabla koja utječe na vjerojatnost izborne participacije na individualnoj razini (Goerres 2007; Northmore-Ball 2016; Allen 2017; Schäfer 2013; Grass 2014). Sindikati imaju mehanizme da politički mobiliziraju svoje članove, smanje informacijske i organizacijske troškove te članovima omoguće aktivno sudjelovanje u društvenima, a često i u specifičnima političkim aktivnostima. No kako se članstvo sindikata smanjuje, posebno u mlađim generacijama radnika koji su izloženiji prekarnim oblicima zaposlenja, najviše se smanjuje participacija mlađih birača nižega socijalno-ekonomskog statusa.

\section{Glas, izlazak i lojalnost hrvatskih birača}

Hrvatsku politiku obilježilo je postojanje jakih ideoloških, identitetskih i simboličkih rascjepa na kojima je 1990. uspostavljen stranački sustav. Ti rascjepi oblikuju političke identitete, ideološke orijentacije i ponašanje birača od 1990. Povezanost odnosa prema povijesti, religiji i tradiciji te njihovo spajanje $\mathrm{u}$ jedan rascjep uzrokovali su formiranje jedne dominantne dimenzije političkog natjecanja, što je posljedovalo izraženom bipolarizacijom stranačkog sustava (Zakošek i Čular 2004; Henjak, Zakošek i Čular 2013; v. i Casal Bertoa 2014; O'Dwyer 2014). Istodobno, niska razina strukturiranosti ekonomskih interesa, vrlo mala važnost ekonomskih pitanja kao odrednice ponašanja birača te činjenica da birači više vrednuju ekonomsko stanje na temelju svoga odnosa prema političkim strankama nego stvarnog sta- 
nja ekonomije (Dolenec 2013; Henjak 2008; Glaurdić i Vuković 2016) stvorili su uvjete u kojima je bilo teško trajno mobilizirati birače na osnovi novih političkih, interesnih ili ideoloških pitanja. U kontekstu u kojemu se političko natjecanje strukturiralo na dva ideološki jasno suprotstavljena i izrazito polarizirana bloka, nove su stranke vrlo teško mogle postati relevantnima političkim akterima koji se mogu natjecati sa starim strankama lijevoga i desnog bloka. Birači koji se ne identificiraju s jednim od blokova, odnosno s etabliranima političkim strankama ljevice i desnice, mogli su birati između prosvjednog glasovanje za nove stranke, koje pak nisu mogle znatnije utjecati na dinamiku stranačkog natjecanja, i izborne apstinencije.

Studije izborne apstinencije u Hrvatskoj utvrdile su postojanje dviju skupina apstinenata (Lamza Posavec 2004). Prvu skupinu čine birači koji su nezainteresirani za politiku ili ne vjeruju da glasovanjem u izborima mogu mijenjati politiku. Drugu skupinu čine birači koji su nezadovoljni stanjem u zemlji, načinom funkcioniranja demokracije i djelovanjem političke elite na vlasti. Zapravo se može kazati da prvu skupinu čine građani koji su izabrali opciju izlaska iz politike i pasivizaciju, dok drugu skupinu čine građani koji se, pod uvjetom da vjeruju kako se participacijom može mijenjati politika, mogu mobilizirati porukama novih političkih aktera koji traže promjenu modela politike i smjenu političkih elita.

Stoga se može pretpostaviti da osnovnu razliku između birača novih i starih stranaka čini njihov odnos prema glavnim elementima politike u posttranzicijskoj Hrvatskoj: odnos prema političkim rascjepima, to jest pripadnost političkim identitetima nastalima na njima, odnos prema političkim institucijama i političkim elitama, zadovoljstvo demo- kracijom i stanjem ekonomije. Birači starih stranaka trebali bi znatno povoljnije gledati na institucije i elite, funkcioniranje demokracije i stanje ekonomije te bi bili povezaniji s tradicionalnima političkim identitetima od birača novih stranaka. Istodobno, sličan je odnos birača novih i starih stranaka prema politici, odnosno prema razini percepcije da mogu utjecati na političke događaje, kao i prema razinama političke informiranosti i uključenosti u politiku. Može se pretpostaviti i to da apstinenti dijele s biračima novih stranaka nezadovoljstvo politikom, političkim institucijama i elitama, funkcioniranjem demokracije i ekonomijom. No birači novih stranaka politički su informiraniji od apstinenata i skloniji vjerovati da se političkim djelovanjem može utjecati na javne politike i djelovanje vlasti.

S obzirom na to da su ekonomski čimbenici vrlo slabo utjecali na političke podjele u Hrvatskoj u sklopu dominacije ideoloških i identitetskih čimbenika, očekivano bi bilo da se građani koji su izloženi visokome ekonomskom riziku i socijalnoj isključenosti slabije identificiraju s političkim identitetima i starima političkim strankama. Budući da stare stranke ne predstavljaju njihove interese i ne nude rješenja njihovih problema, očekivano bi bilo da građani koji su socijalno isključeni i izloženi visokoj razini ekonomskog rizika budu skloniji podržati nove stranke ili ne sudjelovati u izborima. Malo bi vjerojatnije bilo da ti birači neće izaći na izbore nego da će poduprijeti nove stranke.

\section{Podaci i varijable}

U radu testiram navedene pretpostavke pomoću podataka anketnih istraživanja provedenih neposredno nakon parlamentarnih izbora 2015. i 2016. Primaran su izvor podataka ankete koje je proveo istraživački tim Fakulteta političkih znanosti u Zagrebu na slučajnome na- 
cionalnom uzorku od tisuću ispitanika. Anketni podaci za 2015. i 2016. spojeni su u jednu bazu podataka, to jest analiza je obavljena na kombiniranom uzorku, što je bilo moguće zato što je u objema anketama korišten isti upitnik. U kombiniranom uzorku bila su 1.894 valjana analitička slučaja.

Budući da izborne ankete nisu sadržavale dovoljno podataka o socijalno-ekonomskom položaju ispitanika, njihovoj izloženosti socijalnim rizicima i socijalnoj isključenosti, analiza utjecaja tih čimbenika oslanja se na podatke prikupljene anketom što je provedena u sklopu projekta "Žene na tržištu rada" na nacionalnome slučajnom uzorku od 1.260 ispitanika početkom 2016. U sklopu te ankete prikupljeni su podaci o socijalno-ekonomskom položaju ispitanika, njihovih partnera i kućanstava, kao i podaci o njihovu položaju na tržištu rada, izloženosti socijalnom riziku, izvorima prihoda i obrascima potrošnje. Od 1.260 ispitanika, dostupni su podaci o izbornom ponašanju 895 ispitanika, dok je 365 ispitanika odbilo odgovoriti na ta pitanja. Iako je stopa odbijanja vrlo visoka, nema naznaka da u anketi postoji sustavan obrazac odbijanja odgovora s obzirom na varijable koje su korištene $\mathrm{u}$ analizi, odnosno nema naznaka da se ispitanici koji su odbili odgovoriti znatnije razlikuju od bilo koje kategorije ispitanika koji su izrazili izborne preferencije. No valja napomenuti da su ispitanici koji su odbili odgovoriti na pitanje o biračkom ponašanju prema svojim obilježjima na varijablama koje su korištene u analizi sličniji izbornim apstinentima nego biračima.

Kako se u radu koriste dva različita izvora podataka koji nemaju kompatibilne varijable, odnosno nemaju potpuno jednak skup varijabla dostupan za analizu, statistička analiza podataka provedena je u dvije odvojene regresije.
Ovisna varijabla u objema analizama mjeri biračko ponašanje ispitanika i kodirana je u tri kategorije: (a) birače starih stranaka, odnosno stranaka koje korijene imaju u devedesetim godinama, (b) birače novih stranaka, odnosno stranaka nastalih nakon 2000. koje nemaju organizacijski i kadrovski izvor u prvoj skupini stranaka i (c) izborne apstinente. Prvu kategoriju čine birači stranaka koje korijene vuku iz devedesetih godina i stranaka koje su nastale njihovim cijepanjem ili spajanjem: HDZ, SDP, IDS, HSS, HNS, HSLS i razne pravaške stranke. Drugu kategoriju čine ispitanici koji su glasovali za nove stranke: Most, Živi zid, Stranku rada i solidarnosti, HDSSB i Pametno. Treća kategorija uključuje ispitanike koji nisu glasovali u izborima. Kriterij koji je korišten u grupiranju stranaka u osnovi dijeli stranke koje su nastale devedesetih godina na temelju identitetskih, vrijednosnih i teritorijalnih rascjepa mobiliziranih nakon stjecanja državne neovisnosti (Zakošek i Čular 2004) od stranaka koje su nastale kao reakcija na model politike u kojemu su dominirale te stranke. Sukladno tom kriteriju, HDSSB i Stranka rada i solidarnosti svrstani su u nove stranke, iako su ih osnovali političari koji su bili istaknuti članovi HDZ-a i SDP-a devedesetih godina.

U kombiniranom uzorku nastalome iz anketa provedenih 2015. i 2016. godine, 46,4 posto ispitanika izrazilo je potporu starim strankama, 18,2 posto novim strankama, a 35,4 posto odgovorilo je da nisu glasovali. $U$ anketi o tržištu rada iz 2015. godine, 44,6 posto ispitanika podržalo je stare, 16,5 posto nove stranke, a 39.9 posto ispitanika odgovorilo je da nisu izašli na izbore. Valja napomenuti da je broj ispitanika koji su odgovorili da nisu glasovali veći nego što je uobičajeno u izbornim anketama. Ispitanici su skloni odgovarati da su glasovali na izborima i onda kada nisu stvarno glaso- 
vali; osim toga, izborni apstinenti manje su skloni sudjelovati u anketama (Karp i Brockington 2005). U korištenim podacima nema vidljivih naznaka da uzorak nije reprezentativan.

Neovisne varijable mjere povjerenje $\mathrm{u}$ institucije, zadovoljstvo demokracijom, preferiranje demokracije nasuprot vlasti jakih vođa, odnos prema političkim elitama, političku efikasnost, političku informiranost i evaluaciju stanja ekonomije. Općenitije, te varijable mjere odnos ispitanika prema političkom sustavu, političkim elitama i načinu funkcioniranja demokracije. Druga skupina varijabla mjeri odnos prema povijesti, političkim rascjepima i političkim podjelama u Hrvatskoj. Ostale varijable uključuju dob, spol, obrazovanje i religioznost ispitanika.

Politička efikasnost, odnosno percepcija mogućnosti građana da utječu na političke događaje, mjeri se kao prosječna vrijednost dviju varijabla: prva mjeri suglasnost ispitanika s tvrdnjom da je važno tko je na vlasti, a druga mjeri suglasnost ispitanika s tvrdnjom da to za koga građani glasuju u izborima utječe na događaje u zemlji. Korelacija između tih dviju varijabla iznosi $0,519 \mathrm{u}$ anketi 2015. godine, 0,627 u anketi 2016. te 0,713 u anketi o tržištu rada 2015. Više vrijednosti te varijable označavaju višu razinu percepcije političke efikasnosti.

Zadovoljstvo demokracijom mjeri se pitanjem kojim se od ispitanika traži da ocijene svoje zadovoljstvo načinom na koji demokracija funkcionira u Hrvatskoj, pri čemu više vrijednosti na toj varijabli označavaju višu razinu zadovoljstva demokracijom. Preferencija demokracije mjeri se tako da se ispitanike pita je li demokracija uvijek najbolji oblik političke vladavine ili je ponekad potreban jak vođa. Varijabla je kodirana binarno, pri čemu viša vrijednosti označava stav da je demokracija uvijek bolja od vlasti jakih vođa. Varijabla koja mjeri odnos prema demokraciji i vođama nije dostupna u anketi o tržištu rada.

Povjerenje u političke institucije mjeri se kao prosječna vrijednost šest varijabla kojima se od ispitanika tražilo da izraze stupanj povjerenja u predsjednika/predsjednicu države, vladu, Sabor, državnu upravu, sudstvo i političke stranke. Varijabla je kreirana izračunavanjem srednje vrijednosti tih šest varijabla. Cronbach alpha indeks pouzdanosti za tu varijablu iznosi $0,835 \mathrm{u}$ anketi 2015 . godine, 0,874 $\mathrm{u}$ anketi 2016. te $0,902 \mathrm{u}$ anketi o tržištu rada 2015. Više vrijednosti označavaju višu razinu povjerenja u institucije.

Odnos prema političkim elitama mjeren je kao aritmetička sredina varijabla koje se temelje na pitanju jesu li ispitanici suglasni s tvrdnjom da su demokratske procedure samo "predstava za narod", dok se prave odluke donose drugdje, te misle li da politički skandali pokazuju da elite zlorabe političke institucije kada su ugroženi njihovi interesi. Korelacija tih dviju varijabla iznosi 0,554 u anketi 2015. i 0,357 u anketi 2016 . Više vrijednosti te varijable označavaju negativan odnos prema političkim elitama. Te varijable nisu dostupne $\mathrm{u}$ anketi o tržištu rada.

Politička informiranost mjeri se pomoću četiriju pitanja koja provjeravaju činjenično znanje ispitanika o politici: tko je bio ministar financija prije izbora, koja je institucija zadužena za vođenje monetarne politike u zemlji, koje je najviše sudbeno tijelo i tko je predsjednik Europske komisije. Varijabla je kreirana zbrajanjem točnih odgovora i standardizacijom zbrojenih vrijednosti, te je potom putem Blomove transformacije pretvorena $\mathrm{u}$ kontinuiranu varijablu $\mathrm{s}$ normalnom distribucijom. Tako kreirana varijabla ima teorijsku distribuciju vrijednosti od 0 (potpuna neinformiranost) do 1 (potpuna informiranost), pri 
čemu su odgovori rangirani tako da pitanja na koja je točno odgovorio manji broj ispitanika imaju veću težinu, odnosno označavaju višu razinu političke informiranosti (Bartels 1996; Toka 2004). Te varijable nisu dostupne $\mathrm{u}$ anketi o tržištu rada.

Evaluacija stanja ekonomije mjerena je kao srednja vrijednosti dviju varijabla: prva mjeri ispitanikovu ocjenu stanja nacionalne ekonomije $\mathrm{u}$ odnosu prema razdoblju prije posljednjih izbora, a druga mjeri procjenu ispitanika o ekonomskom stanju njegove obitelji u odnosu prema istom razdoblju. Više vrijednosti te varijable označavaju pozitivnu evaluaciju ekonomskog stanja. Korelacija između tih dviju varijabla iznosi $0,757 \mathrm{u}$ anketi 2015. godine, 0,762 u anketi 2016 . te 0,608 u anketi o tržištu rada 2015 .

Odnos prema političkim podjelama mjeren je kao aritmetička sredina dviju varijabla koje se temelje na pitanju jesu li ispitanici suglasni s tvrdnjom da je spominjanje događaja iz Drugoga svjetskog rata štetno zato što odvraća pozornost građana $s$ bitnih sadašnjih problema $u$ zemlji, te jesu li suglasni s tvrdnjom da prozivanje i napadanje političkih suparnika zbog nedostatka domoljublja stvara opasne podjele u hrvatskom društvu. Korelacija tih dviju varijabla iznosi 0,326 u anketi 2015. i 0,495 u anketi 2016. Više vrijednosti te varijable označavaju negativan odnos prema političkoj polarizaciji u Hrvatskoj. Te varijable nisu dostupne u anketi o tržištu rada.

Odnos prema povijesti mjeren je kao prosječna vrijednost dviju varijabla koje mjere ocjenu pozitivne ili negativne povijesne uloge Ante Pavelića i Josipa Broza Tita kao povijesnih osoba koje personificiraju pokrete, ideologije i režime kojima su bili na čelu 1941-1945, odnosno 1945-1980. Ispitanicima koji su indiferentni ili ne znaju kako procijeniti ulogu tih povijesnih ličnosti do- dijeljena je srednja vrijednost varijable. Varijabla je kreirana oduzimanjem apsolutne vrijednosti ocjene ispitanika od srednje vrijednosti skale i uzimanjem prosječne vrijednosti tih dviju varijabla. Više vrijednosti varijable označavaju kombinaciju izrazito negativne i izrazito pozitivne procjene uloge tih povijesnih ličnosti, što ponajprije razlikuje ispitanike koji imaju neinformiran ili indiferentan odnos prema povijesti i ispitanike koji imaju formiran pozitivan odnosno negativan odnos prema "lijevoj" ili "desnoj" interpretaciji povijesti. Te varijable nisu korištene u anketi o tržištu rada.

Obrazovanje je mjereno kao najviši završeni stupanj obrazovanja ispitanika. Religioznost je mjerena kao odnos ispitanika prema religiji: najviša vrijednost varijable označava uvjerene vjernike, a najniža nevjernike. Dob je mjerena kao broj godina ispitanika u vrijeme ankete, dok je spol mjeren kao binarna varijabla, pri čemu viša vrijednost označava žene.

Navedene varijable koje se pojavljuju u objema anketama mjerene su na jednak način, budući da obje ankete koriste identične dijelove upitnika. Anketa o položaju žena na tržištu rada, iz koje su uzeti podaci za analizu utjecaja socijalno-ekonomskih čimbenika, nema varijable koje mjere odnos prema demokraciji ili vođama, političku informiranost, odnos prema povijesti, političkim elitama i političkim podjelama. No ta anketa uključuje dodatne varijable koje su potrebne da bi se precizno mjerio socijalno-ekonomski položaj ispitanika i njegova kućanstva pomoću imovine kućanstva, socijalne isključenosti kućanstva, izloženosti ispitanika riziku nezaposlenosti, izloženosti kućanstva kreditnim zaduženjima i zaposlenosti ispitanika u privatnome ili javnom sektoru.

Varijabla koja mjeri imovinski status kućanstva mjerena je kao prosječna vrijednost sedam varijabla koje mjere 
vrstu imovine koju posjeduje kućanstvo, poput raznih vrsta nekretnina, kao i sposobnost kućanstva da zadovolji svoje materijalne potrebe i potrošnju. Više vrijednosti te varijable izražavaju višu imovinsku razinu kućanstva.

Varijabla koja mjeri socijalnu isključenost kućanstva mjerena je kao prosječna vrijednost sedam varijabla koje mjere sposobnost kućanstva da zadovolji osnovne životne potrebe vlastitim resursima, odnosno raznim oblicima pomoći izvana. Više vrijednosti te varijable označavaju višu razinu socijalne isključenosti.

Varijabla koja mjeri rizik od nezaposlenosti mjerena je kao prosječna standardizirana vrijednost dviju varijabla koje mjere percepciju vjerojatnosti ispitanika da će u sljedećih šest mjeseci izgubiti posao i percepciju vjerojatnosti da će, ako izgube posao, naći slično plaćen posao. Više vrijednosti te varijable označavaju višu razinu rizika od nezaposlenosti.

Varijabla koja mjeri izloženost kreditu kreirana je kao prosječna vrijednost pet varijabla koje mjere koliko je kućanstvo ispitanika izloženo raznim vrstama kreditnog zaduženja: od stambenoga, dugoročnog, namjenskog i potrošačkog kredita do duga na tekućem računu i kreditnim karticama. Više razine te varijable označavaju višu razinu kreditnog zaduženja ispitanika. Posljednja varijabla kodirana je kao binarna varijabla gdje vrijednost 1 označava zaposlene u privatnome, a 0 zaposlene $\mathrm{u}$ javnom ili neprofitnom sektoru.

\section{Rezultati}

Kako je neovisna varijabla mjerena na nominalnoj razini, u radu se koristi multinominalna logistička regresija kao metoda analize podataka. Rezultati multinominalne regresije prikazani su u tablicama 1. i 2. Tablica 1. prikazu- je rezultate analize podataka iz kombiniranih uzoraka anketa provedenih nakon izbora 2015. i 2016, a tablica 2. prikazuje rezultate posebne analize zasnovane na podacima ankete o tržištu rada koja uključuje varijable koje mjere socijalno-ekonomski položaj ispitanika i njegova kućanstva. Kako bi se dobila potpunija slika rezultata, u obje regresije prikazani su koeficijenti koji međusobno uspoređuju sve tri kategorije ovisne varijable, odnosno prikazuju rezultate u tri binarne usporedbe. Da bi se lakše usporedili supstantivni učinci pojedinih varijabla i procijenila snaga njihovih učinaka, utjecaj svih varijabla u analizi prikazan je na slikama koje pokazuju koliko se mijenjaju vjerojatnosti glasovanja za stare ili nove stranke, odnosno vjerojatnosti izborne apstinencije kada se mijenjaju vrijednosti pojedine neovisne varijable. Na slikama su prikazani supstantivni efekti samo za statistički značajne varijable.

Rezultati multinominalne logističke regresije prikazani u tablici 1 . pokazuju da temeljnu razliku između birača starih i novih stranaka, s jedne, te apstinenata, s druge strane, čini razina njihove uključenosti u politiku. Rezultati regresije pokazuju, također, da su birači starih i novih stranaka obrazovaniji, politički informiraniji i da imaju izraženiji osjećaj vlastite političke efikasnosti od izbornih apstinenata. Pritom birači novih stranaka imaju donekle nižu razinu političke efikasnosti od birača starih stranaka, što je očekivano s obzirom na to da podržavaju stranke koje kritiziraju status quo i traže promjenu politike. Istodobno, izborni su apstinenti politički neinformiraniji i ne vjeruju da mogu utjecati na političke događaje. U osnovi, taj nalaz potvrđuje očekivanja i u skladu je s nalazima komparativnih studija razlika između birača i apstinenata u drugim zemljama (Karp i Banducci 2008; 
Tablica 1. Multinominalna regresija odrednica izborne apstinencije, glasovanja za stare i nove stranke u izborima 2015. i 2016.

\begin{tabular}{|c|c|c|c|}
\hline & $\begin{array}{c}\text { Stare stranke/ } \\
\text { Apstinenti } \\
\text { b/se }\end{array}$ & $\begin{array}{l}\text { Nove stranke/ } \\
\text { Apstinenti } \\
\text { b/se }\end{array}$ & $\begin{array}{c}\text { Nove stranke/ } \\
\text { Stare stranke } \\
\text { b/se }\end{array}$ \\
\hline \multirow[t]{2}{*}{ Politička efikasnost } & $0,729^{\star *}$ & $0,581^{\star \star}$ & $-0.148^{\star}$ \\
\hline & $(0,058)$ & $(0,068)$ & $(0.067)$ \\
\hline \multirow[t]{2}{*}{ Kritika političkih podjela } & $-0,067$ & 0,061 & 0.128 \\
\hline & $(0,061)$ & $(0,075)$ & $(0.070)$ \\
\hline \multirow[t]{2}{*}{ Kritika političkih elita } & $-0,215^{\star *}$ & 0,080 & $0.295^{\star *}$ \\
\hline & $(0,076)$ & $(0,095)$ & $(0.089)$ \\
\hline \multirow[t]{2}{*}{ Demokracija ili vođe } & $-0,256^{\star}$ & $-0,214$ & 0.041 \\
\hline & $(0,118)$ & $(0,142)$ & $(0.133)$ \\
\hline \multirow[t]{2}{*}{ Zadovoljstvo demokracijom } & 0,025 & $-0,079$ & -0.104 \\
\hline & $(0,051)$ & $(0,062)$ & $(0.057)$ \\
\hline \multirow[t]{2}{*}{ Povjerenje u institucije } & 0,052 & 0,020 & -0.032 \\
\hline & $(0,079)$ & $(0,098)$ & $(0.093)$ \\
\hline \multirow[t]{2}{*}{ Evaluacija stanja ekonomije } & $0,214^{*}$ & $-0,091$ & $-0.305^{\star *}$ \\
\hline & $(0,087)$ & $(0,102)$ & $(0.096)$ \\
\hline \multirow[t]{2}{*}{ Spol } & $-0,215$ & 0,120 & $0.335^{\star}$ \\
\hline & $(0,118)$ & $(0,143)$ & $(0.134)$ \\
\hline \multirow[t]{2}{*}{ Dob } & $0,018^{\star \star}$ & $-0,011^{\star}$ & $-0.028^{\star *}$ \\
\hline & $(0,004)$ & $(0,005)$ & $(0.004)$ \\
\hline \multirow[t]{2}{*}{ Religioznost } & $0,138^{*}$ & 0,064 & -0.074 \\
\hline & $(0,058)$ & $(0,069)$ & $(0.066)$ \\
\hline \multirow[t]{2}{*}{ Obrazovanje } & $0,111^{\star}$ & $0,138^{*}$ & 0.027 \\
\hline & $(0,056)$ & $(0,066)$ & $(0.060)$ \\
\hline \multirow[t]{2}{*}{ Politička informiranost } & $0,193^{* *}$ & $0,186^{* *}$ & -0.008 \\
\hline & $(0,026)$ & $(0,032)$ & $(0.030)$ \\
\hline \multirow[t]{2}{*}{ Odnos prema povijesti } & $0,332^{\star \star}$ & $-0,003$ & $-0.335^{\star *}$ \\
\hline & $(0,095)$ & $(0,115)$ & $(0.108)$ \\
\hline \multirow[t]{2}{*}{ Konstanta } & $-3,761^{* *}$ & $-3,024$ & 0.737 \\
\hline & $(0,629)$ & $(0,753)$ & $(0.723)$ \\
\hline $\mathrm{N}$ & 1894 & & \\
\hline LR chi ${ }^{2}$ & 480,64 & & \\
\hline Prob $>$ chi $^{2}$ & 0,000 & & \\
\hline Pseudo $\mathrm{R}^{2}$ & 0,123 & & \\
\hline
\end{tabular}

Jung 2017; Grönlund i Setälä 2007; Goerres 2007).

Birače novih i starih stranaka razlikuje odnos prema političkim elitama i prevladavajućima ideološkim rascjepi- ma, kao i vrednovanje ekonomskog stanja. Birači starih stranaka imaju znatno jasniji odnos prema povijesti od birača novih stranaka i izbornih apstinenata, odnosno birači starih stranaka skloniji su prihvatiti lijevu ili desnu interpreta- 
Slika 2. Utjecaj političke efikasnosti, političke informiranosti i evaluacije stanja ekonomije na vjerojatnost glasovanja

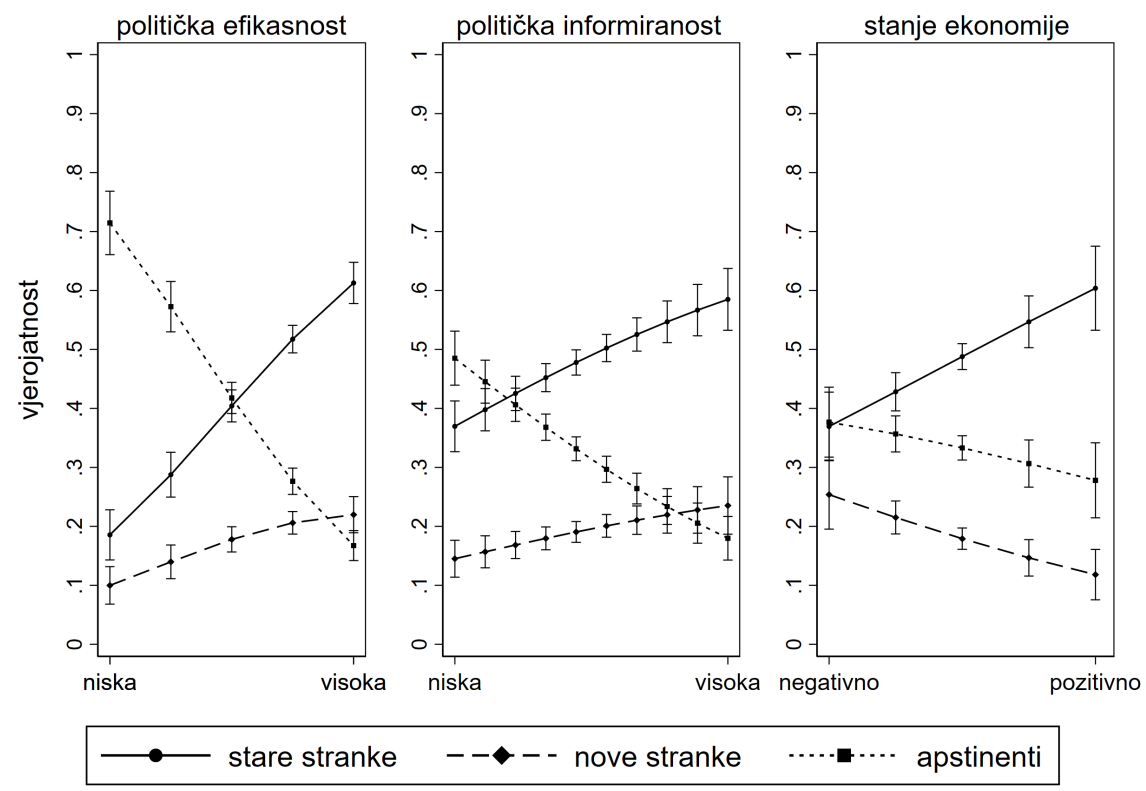

ciju povijesti od birača novih stranaka koji imaju manje polarizirano viđenje povijesti. Nadalje, birači novih stranaka znatno negativnije ocjenjuju stanje ekonomije od birača starih stranka te se u tome ne razlikuju značajno od izbornih apstinenata koji, također, negativno ocjenjuju ekonomsko stanje. Birači starih stranaka imaju pozitivniji odnos prema političkim elitama od birača novih stranaka i izbornih apstinenata, dok birače novih stranaka i apstinente ne razlikuju bitnije njihov odnos prema političkim elitama.

Naposljetku, rezultati prikazani u tablici 1. pokazuju da su izborni apstinenti donekle skloniji preferirati demokraciju od jakih vođa, dok su birači starih stranaka skloniji snažnim vođama. Razlika između tih kategorija i birača novih stranaka nije značajna. Žene su donekle sklonije podržati nove stranke, religiozni ispitanici donekle su skloniji podržati stare stranke, dok su nereligiozni ispitanici skloniji izbornoj apstinenciji.
Što se tiče demografskog profila birača novih stranaka, posebno se značajnim čini to što su birači novih stranaka prosječno značajno mlađi od birača starih stranaka, dok su izborni apstinenti donekle mlađi od birača novih stranaka. Prema dobnoj distribuciji, birači starih stranaka prosječno su najstariji, slijede ih birači novih stranaka, dok su izborni apstinenti najmlađi. ${ }^{3}$

Slika 2. pokazuje supstantivne učinke varijabla koje mjere političku efikasnost, političku informiranost i procjenu stanja ekonomije na vjerojatnost glasovanja za stare i nove stranke te izbornu apstinenciju. Ona pokazuje da najveće supstantivne učinke na biračko ponašanje ima politička efikasnost, slijedi politička informiranost, dok procjena stanja ekonomije ima najslabiji učinak.

3 Analiza na odvojenim uzorcima za izbore 2015. i 2016. pokazuje da je utjecaj glavnih varijabla - političke informiranosti, političke efikasnosti, dobi i odnosa prema povijesti - bio gotovo identičan u izborima 2015. i 2016. 
Slika 3. Utjecaj varijabla koje mjere odnos ispitanika prema povijesti i političkim elitama na vjerojatnost glasovanja

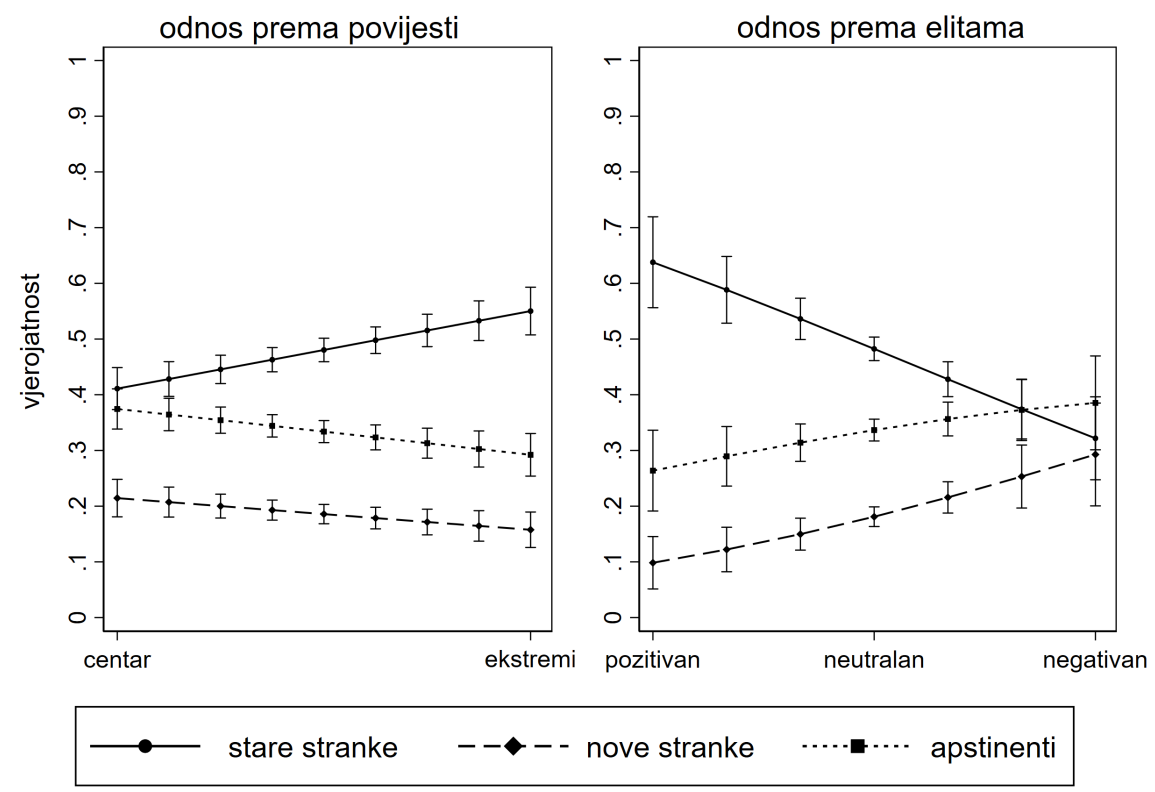

Slika 2. pokazuje da vjerojatnost glasovanja za stare stranke raste s 20 na 60 posto kako se povećava percepcija političke efikasnosti ispitanika od najniže do najviše vrijednosti. Učinak političke efikasnosti na vjerojatnosti glasovanja za nove stranke nešto je slabiji i povećava se s 10 posto na najnižoj do 20 posto na najvišoj razini percepcije političke efikasnosti. Istodobno, vjerojatnost pripadanja kategoriji izbornih apstinenata opada sa 70 posto na najnižoj na 15 posto na najvišoj razini percepcije političke efikasnosti.

Učinak političke informiranosti donekle je slabiji, ali je ipak vrlo značajan. Vjerojatnost glasovanja za stare stranke povećava se s oko 35 na oko 60 posto kako se politička informiranost ispitanika pomiče od najniže k najvišoj razini, dok se vjerojatnost glasovanja za nove stranke otprilike udvostručuje. Istodobno se vjerojatnost pripadanja kategoriji izbornih apstinenta smanjuje s 50 na 15 posto kako se ispitanik pomiče od naj- niže $\mathrm{k}$ najvišoj razini političke informiranosti.

Dok su birači starih i novih stranaka slični prema političkoj informiranosti i percepciji političke efikasnosti, razlikuju se u procjeni stanja ekonomije, pri čemu vjerojatnost podrške novim strankama i nesudjelovanja na izborima opada kako se procjena stanja ekonomije kreće od negativne k pozitivnoj. Slika 2. pokazuje da promjena evaluacije stanja ekonomije od negativne $\mathrm{k}$ pozitivnoj povećava vjerojatnost glasovanja za stare stranke s 40 na 60 posto. Istodobno se smanjuje vjerojatnost glasovanja za nove stranke i izbornu apstinenciju - u prvom slučaju s oko 25 na malo više od 10 posto, a u drugom slučaju s oko 40 na oko 30 posto - kako se evaluacije stanja ekonomije mijenja od negativne k pozitivnoj.

Slika 3. pokazuje učinke druge skupine varijabla koje mjere odnos prema političkim elitama i političkim rascjepima.

Od tih dviju varijabla, odnos prema političkim elitama ima značajnije učin- 
Slika 4. Utjecaj varijabla koje mjere dob i obrazovanje ispitanika na vjerojatnost glasovanja
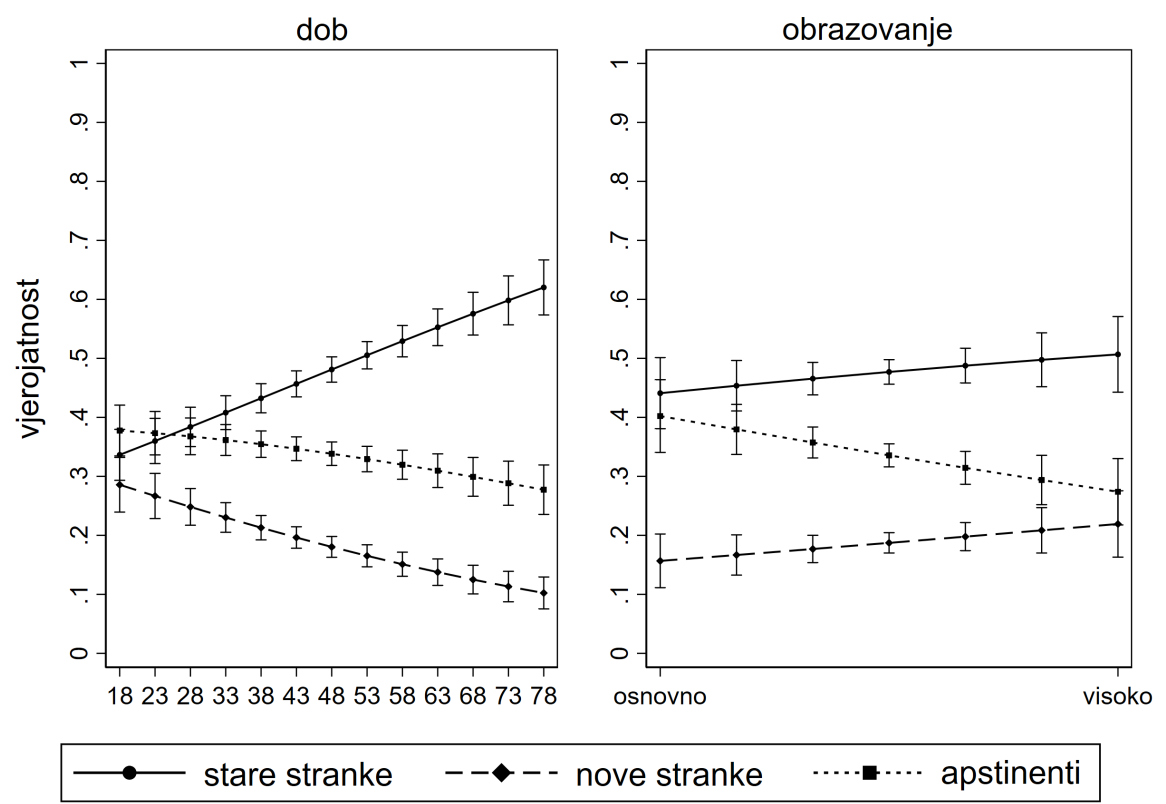

ke. Promjena odnosa prema političkim elitama od pozitivnoga $\mathrm{k}$ negativnome jako smanjuje vjerojatnost glasovanja za stare stranke: s oko 65 na malo više od 30 posto. Istodobno se povećava vjerojatnost izborne apstinencije $s$ malo više od 25 na oko 40 posto, dok se vjerojatnost glasovanja za nove stranke povećava s desetak na tridesetak posto kako se odnos prema političkim elitama mijenja od pozitivnoga $\mathrm{k}$ negativnome. Pogleda li se veličina učinka te varijable, odnos prema političkim elitama jest varijabla koja najviše razlikuje birače novih i starih stranaka, dok su učinci na izborne apstinente nešto slabiji.

Druga varijabla koja ima vidljiv supstantivan učinak na vjerojatnost glasovanja jest odnos prema povijesti. Kretanje od centra k lijevoj i desnoj interpretaciji povijesti povećava vjerojatnost glasovanja za stare stranke s oko 40 na oko 55 posto, dok se vjerojatnost glasovanja za nove stranke i izborna apstinencija smanjuju, ali u znatno manjoj mjeri.
Slika 4. pokazuje supstantivne učinke dviju značajnih varijabla koje mjere socijalno-demografska obilježja ispitanika, dobi i obrazovanja, pri čemu najznačajnije učinke ima dob ispitanika.

Slika 4. pokazuje da povećanje starosti ispitanika u rasponu od 18 do 78 godina povećava vjerojatnost glasovanja za stare stranke s oko 35 na oko 65 posto. Istodobno se trostruko smanjuje vjerojatnost glasovanja za nove stranke, s tridesetak na desetak posto, dok se vjerojatnost izborne apstinencije smanjuje $s$ četrdesetak na tridesetak posto. Pritom valja naglasiti da je kod ispitanika mlađih od 23 godine vjerojatnost apstinencije nešto veća od vjerojatnosti glasovanja za stare stranke. Najmlađi birači zapravo se vrlo malo razlikuju prema vjerojatnosti glasovanja za stare i nove stranke i nesudjelovanja na izborima. Na drugoj strani dobne distribucije, među najstarijim biračima, vjerojatnost glasovanja za stare stranke veća je od 60 posto, a dvostruko i trostruko je veća 
Tablica 2. Multinominalna regresija odrednica izborne apstinencije, glasovanja za stare i nove stranke u izborima 2015: socijalno-ekonomski model.

\begin{tabular}{|c|c|c|c|}
\hline & $\begin{array}{c}\text { Stare stranke/ } \\
\text { Apstinenti } \\
\text { b/se }\end{array}$ & $\begin{array}{c}\text { Nove stranke/ } \\
\text { Apstinenti } \\
\text { b/se }\end{array}$ & $\begin{array}{c}\text { Nove stranke/ } \\
\text { Stare stranke } \\
\text { b/se }\end{array}$ \\
\hline \multirow[t]{2}{*}{ Dob } & $0,043^{\star \star}$ & $0,019^{\star}$ & $-0.025^{\star \star}$ \\
\hline & $(0,008)$ & $(0,009)$ & $(0.009)$ \\
\hline \multirow[t]{2}{*}{ Spol } & $-0,589^{* *}$ & $-0,205$ & 0.384 \\
\hline & $(0,196)$ & $(0,246)$ & $(0.228)$ \\
\hline \multirow[t]{2}{*}{ Religioznost } & $0,243^{\star *}$ & 0,113 & -0.130 \\
\hline & $(0,106)$ & $(0,109)$ & $(0.104)$ \\
\hline \multirow[t]{2}{*}{ Obrazovanje } & $0,200^{* *}$ & $0,313^{\star *}$ & 0.112 \\
\hline & $(0,074)$ & $(0,087)$ & $(0.075)$ \\
\hline \multirow[t]{2}{*}{ Bogatstvo kućanstva } & $0,174^{\star *}$ & $0,211^{\star *}$ & 0.037 \\
\hline & $(0,059)$ & $(0,075)$ & $(0.071)$ \\
\hline \multirow[t]{2}{*}{ Socijalna isključenost } & $-0,196^{*}$ & $-0,170$ & 0.026 \\
\hline & $(0,088)$ & $(0,114)$ & $(0.111)$ \\
\hline \multirow[t]{2}{*}{ Rizik nezaposlenosti } & $-0,130$ & $-0,133$ & -0.003 \\
\hline & $(0,110)$ & $(0,144)$ & $(0.136)$ \\
\hline \multirow[t]{2}{*}{ Privatni sektor } & $-0,509^{*}$ & $-0,473$ & 0.036 \\
\hline & $(0,208)$ & $(0,261)$ & $(0.236)$ \\
\hline \multirow[t]{2}{*}{ Izloženost kreditu } & $0,531^{\star}$ & $0,644^{*}$ & 0.114 \\
\hline & $(0,213)$ & $(0,259)$ & $(0.230)$ \\
\hline \multirow[t]{2}{*}{ Povjerenje $\mathrm{u}$ institucije } & $0,498^{* *}$ & 0,237 & -0.261 \\
\hline & $(0,146)$ & $(0,188)$ & $(0.171)$ \\
\hline \multirow[t]{2}{*}{ Zadovoljstvo demokracijom } & 0,245 & $-0,246$ & $-0.491^{\star \star}$ \\
\hline & $(0,135)$ & $(0,176)$ & $(0.166)$ \\
\hline \multirow[t]{2}{*}{ Ocjena ekonomskog stanja } & 0,083 & 0,002 & -0.081 \\
\hline & $(0,133)$ & $(0,167)$ & $(0.155)$ \\
\hline \multirow[t]{2}{*}{ Politička efikasnost } & $0,410^{* *}$ & $0,333^{\star \star}$ & -0.077 \\
\hline & $(0,091)$ & $(0,112)$ & $(0.109)$ \\
\hline \multirow[t]{2}{*}{ Konstanta } & $-5,011^{* *}$ & $-4,400^{* *}$ & 1.393 \\
\hline & $(0,962)$ & $(1,186)$ & $(1.145)$ \\
\hline $\mathrm{N}$ & 731 & & \\
\hline LR chi ${ }^{2}$ & 217,030 & & \\
\hline Prob $>$ chi $^{2}$ & 0,000 & & \\
\hline Pseudo $\mathrm{R}^{2}$ & 0,147 & & \\
\hline
\end{tabular}

od vjerojatnosti apstinencije i potpore novim strankama. Supstantivan utjecaj obrazovanja osjetno je slabiji, pri čemu je viša razina obrazovanja povezana $s$ većom vjerojatnošću glasovanja za stare i nove stranke te s nižom vjerojatnošću izborne apstinencije.
Budući da podaci iz izbornih anketa ne mjere dovoljno precizno socijalno-ekonomski položaj ispitanika, kako bi se analizirali učinci tih čimbenika uključena je druga regresija prikazana u tablici 2. koja sadržava skup varijabla koje mjere socijalno-ekonomski 
Slika 5. Utjecaj varijabla koje mjere utjecaj socijalno-ekonomskog položaja na vjerojatnost glasovanja

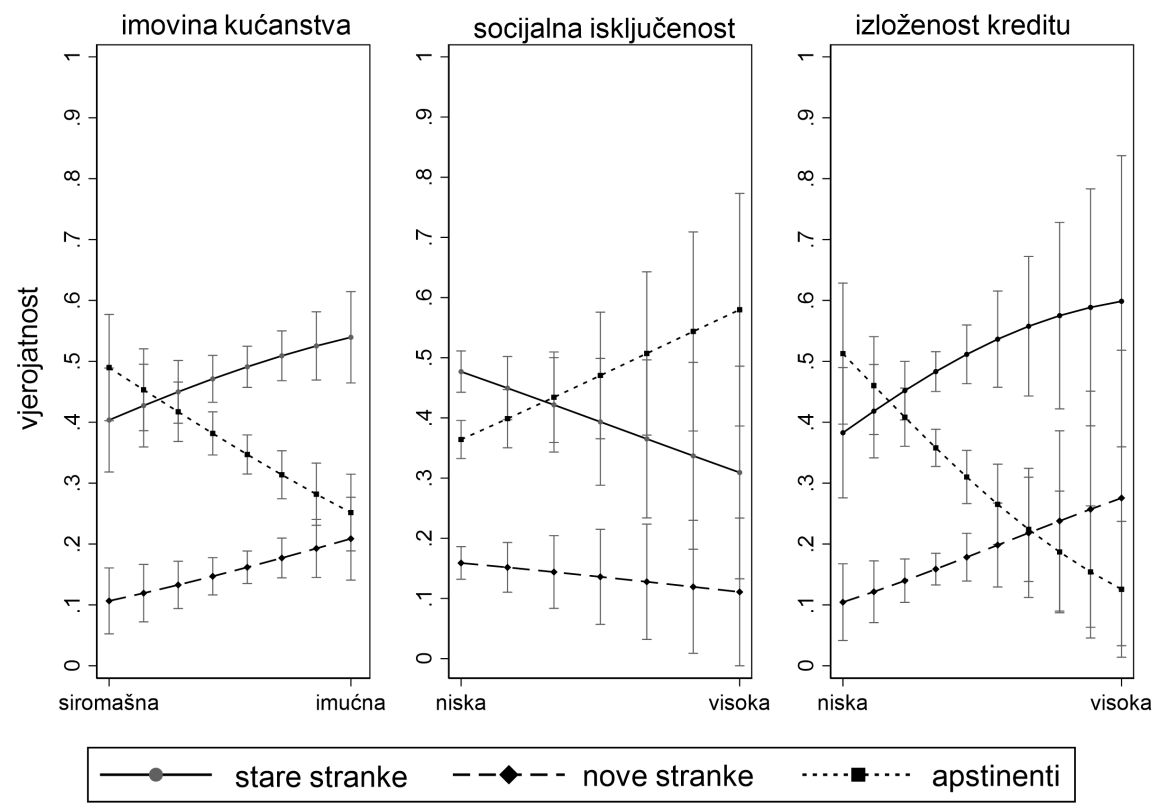

položaj ispitanika. Rezultati prikazani u tablici 2. potvrđuju značenje varijabla, poput političke efikasnosti, dobi i obrazovanja, koji je vidljiv i u tablici 1. No rezultati druge regresije pokazuju da postoje značajne razlike u socijalno-ekonomskom statusu između birača starih i novih stranaka te izbornih apstinenata. Osim što su birači starih i novih stranaka obrazovaniji, oni žive u imućnijim kućanstvima, a pokazalo se i da su izloženiji kreditnim zaduženjima, iako je utjecaj te varijable manje značajan. Nadalje, pokazalo se i to da su apstinenti izloženiji socijalnoj isključenosti i da su češće zaposleni u privatnom sektoru od birača starih stranaka.

Slika 5. prikazuje supstantivne učinke varijabla koje mjere imovinu, socijalnu isključenost i izloženost kućanstava kreditima. Ona pokazuje da porast bogatstva kućanstva povećava vjerojatnost glasovanja za stare i nove stranke u gotovo jednakoj mjeri, za de- setak posto, pri čemu se udvostručuje vjerojatnost glasovanja za nove stranke i povećava vjerojatnost glasovanja za stare stranke za jednu petinu. Istodobno, vjerojatnost izborne apstinencije smanjuje se s 50 na 25 posto kako se imovina kućanstva povećava od najniže $\mathrm{k}$ najvišoj razini, što znači da od najsiromašnijih u izborima sudjeluje samo jedan od dva birača, a od najbogatijih tri od četiri birača.

Slične učinke pokazuju i ostale varijable, iako socijalna isključenosti i izloženost kreditu imaju znatno veće intervale pouzdanosti, što pokazuje da crte na slikama znatno nepreciznije predviđaju vjerojatnost glasovanja ispitanika za stare i nove stranke ili za izbornu apstinenciju.

Slike pokazuju kretanje prosječnih vrijednosti te, unatoč relativno velikim intervalima pouzdanosti, potvrđuju da je utjecaj socijalno-ekonomskog položaja značajan, pogotovo na izborne apstinente. Promjena socijalne isklju- 
čenosti kućanstva od najniže do najviše razine gotovo udvostručuje vjerojatnost izborne apstinencije. Porast izloženosti kreditima od najniže do najviše razine smanjuje vjerojatnost izborne apstinencije s oko 50 na oko 15 posto. Izloženost kreditima najvjerojatnije izražava financijsku sposobnost kućanstava: ispitanici koji žive u kućanstvima s niskim dohotkom i koji su socijalno isključeni nemaju pristup kreditima i oslanjaju se na alternativne strategije preživljavanja. Stoga nalaz, možda, reflektira stanje u kojemu ekonomski isključeni pojedinci ne sudjeluju ni u politici ni u izborima djelomice zato što ne vide mogućnost promjene svoga ekonomskog položaja političkim djelovanjem.

Slika koja proizlazi iz te analize potvrđuje postojanje triju osnovnih čimbenika utjecaja na izbornu apstinenciju. Prvi je čimbenik odnos prema politici: izborni apstinenti imaju znatno manji interes i povjerenje u svoju sposobnost utjecaja na politiku od svih birača uzetih ukupno. Drugi čimbenik koji stvara razliku između birača i apstinenta jest dob i on pokazuje da postoje znatne generacijske razlike u političkoj participaciji. Iz te se analize ne može razabrati jesu li te razlike povezane sa životnim ciklusima pojedinaca u kojima birači postaju skloniji sudjelovati u izborima kako stare ili imaju dublje korijene i ukazuju na to da su mlađe generacije nesklonije sudjelovati u izborima te da bi se taj trend mogao produljiti i u kasnijim fazama života. Činjenica da se ukupna razina participacije smanjuje (slika 1) ukazuje na to da je posve moguće kako su posrijedi generacijski učinci koji će opstati i u budućnosti. No da bi se došlo do posve pouzdana uvida u taj trend, potrebno je provesti posebnu analizu. Treći čimbenik koji dijeli apstinente od birača njihov je socijalno-ekonomski status. Apstinente karakteriziraju niži stupanj obrazovanja, slabiji imovinski status i viša razina socijalno-ekonomske isključenosti. Taj je nalaz sukladan nalazima niza komparativnih studija, te u kombinaciji s ostalim rezultatima upućuje na mogućnost oblikovanja trajnog obrasca izborne apstinencije, odnosno političke isključenosti, ako dođe do konvergencije tih triju čimbenika.

Što se tiče razlika između birača novih i starih stranaka, analiza je pokazala da se razlikuje njihov odnos prema političkim rascjepima koji su dominirali hrvatskom politikom. Birači novih stranaka zauzimaju centrističku poziciju u odnosu prema novijoj hrvatskoj povijesti, dok su birači starih stranaka skloniji izrazitijoj lijevoj i desnoj interpretaciji povijesti. Drugu osnovnu razliku čini odnos birača novih stranaka prema efikasnosti političkog sustava i političkim elitama. Kombinacija tih dvaju čimbenika pokazuje da su birači novih stranaka udaljeni od lijevih i desnih političkih identiteta i elita, te da se vrlo vjerojatno nalaze na novoj dimenziji natjecanja koja dijeli sustavske od protusustavskih pozicija. Iz te se analize ne može razabrati postoji li neki dodatan sadržaj na toj dimenziji te tek treba vidjeti jesu li nove stranke prolazan fenomen ili će postati trajniji akteri koji će mobilizirati novu dimenziju natjecanja.

\section{Zaključak}

Cjelovita analitička slika potvrđuje da se razlike između birača novih i starih stranaka te izbornih apstinenata poklapaju s hipotetskim očekivanjima. Analiza potvrđuje očekivanja da se birači novih i starih stranka razlikuju od izbornih apstinenata prema procjeni vlastite mogućnosti utjecaja na politiku i razini političke informiranosti. Nadalje, izborni su apstinenti slabije obrazovani i imaju manje ekonomskih resursa od birača starih i novih stranaka. Izborne apstinente karakteriziraju dvije sastavnice isključenosti: jedna proistječe iz nedo- 
statka interesa i vjere u smisao vlastitoga političkog djelovanja, a druga iz lošijega socijalno-ekonomskog položaja. Te se dvije komponente $\mathrm{u}$ jednom segmentu izbornih apstinenata poklapaju i međusobno pojačavaju te posljedično smanjuju vjerojatnost da izborni apstinenti postanu birači.

Osim političke i socijalo-ekonomske isključenosti, izborni apstinenti razlikuju se od birača i prema dobi. Analiza pokazuje da je u najmlađima dobnim skupinama birača vjerojatnost izborne participacije gotovo jednaka vjerojatnosti izborne apstinencije. Taj nalaz može reflektirati općenito nižu razinu participacije mlađih birača, koja može biti privremena i može se mijenjati kako birači budu starjeli. No, ako dobna razlika u razini participacije nije privremena pojava - a to je moguće s obzirom na to da je prethodna sklonost sudjelovanju na izborima važna odrednica buduće izborne participacije - očekivano bi bilo da ukupna razina izborne participacije dugoročno tendencijski pada s mogućima kratkoročnim oscilacijama na važnijim izborima (Czesnik, Zerkowska-Balas i Kotnarowski 2013).

Rezultati analize potvrđuju da se birači novih stranaka i izborni apstinenti razlikuju, ali i da uvelike dijele sličan odnos prema političkim rascjepima, političkim elitama i procjeni ekonomskog stanja. Izborni su apstinenti nezadovoljniji političkim elitama i stanjem ekonomije i nezainteresiraniji za tradicionalne političke rascjepe. To može biti posljedica konteksta u kojemu su politički socijalizirani, a kojim su dominirali ideološki rascjepi i kartel etabliranih političkih stranaka, ali i izraz razočaranja u političke elite i model politike u kojemu se stranačko natjecanje strukturira poglavito oko ideoloških i identitetskih rascjepa. U tom se slučaju nezadovoljstvo politikom i političkim elitama, kao i ekonomskim stanjem na koje po- litičke elite nemaju odgovora, a imajući $u$ vidu nedostatak izbornih alternativa $i$ vlastitu percepciju da se sudjelovanjem u izborima ne može utjecati na politiku, pretvorilo u izbornu apstinenciju.

No kada se pojave nove stranke, birači koji su nezadovoljni političkim sustavom i političkim elitama mogu glasovati za njih. Nove stranke stanovito su političko osvježenje koje pridonosi mobilizaciji nezadovoljnih birača, koji bi inače postali izborni apstinenti, kao i stabilizaciji političke participacije. Utjecaj novih stranaka na mobilizaciju izbornih apstinenata ograničen je pak na birače koji vjeruju da sudjelovanjem u izborima mogu utjecati na politiku. No to može značiti da se znatan dio birača, koje obilježuje kombinacija niskoga socijalno-ekonomskog statusa, niskog stupnja političke informiranosti i nedostatak vjere u mogućnost osobnog utjecaja na politiku, pretvorio u stalne izborne apstinente, što može trajno smanjiti izbornu participaciju u Hrvatskoj.

Za kvalitetu političkog predstavništva i budućnost stranačkog sustava, a posebice za razvoj njegove kompetitivne dinamike, veliko značenje može imati osjetno slabija izborna participacija birača nižega socijalno-ekonomskog statusa. S jedne strane, taj nalaz može značiti da interesi ekonomski isključenih građana neće biti predstavljeni u procesu donošenja političkih odluka. S druge strane, to što mlađi građani i građani nižega socijalno-ekonomskog statusa ne glasuju otvara znatno veći prostor novim strankama da mobiliziraju širu izbornu potporu od one koju su dosad imale. Ako nove stranke uspiju izraditi političke programe kojima mogu mobilizirati te birače, erozija potpore starim strankama mogla bi se nastaviti, a razina potpore novim strankama znatno približiti razini podrške starim strankama. 


\section{Literatura}

Allen, Trevor. 2017. Exit to the right? Comparing far right voters and abstainers in Western Europe. Electoral Studies. (50) 6: 103-115. Doi.org /10. 1016/j.electstud.2017.09.012

Anderson, Christopher, Beramandi, Pablo. 2012. Left Parties, Voters and Electoral Participation in Advanced Industrial Societies. Comparative Political Studies. (45) 6: 714-746. doi.org/ 10.1177/0010414011427880

Bagić, Dragan. 2007. Društveni rascjepi i stranačke preferencije na izborima za Hrvatski sabor 2003. godine. Politička misao. (44) 4: 93-115.

Bartels, Larry. 1996. Uninformed Votes: Information Effects in Presidential Elections. American Journal of Political Science. (40) 1: 194-230. DOI: $10.2307 / 2111700$

Casal Bertoa, Fernando. 2014. Party systems and cleavage structures revisited: A sociological explanation of party system institutionalization in East Central Europe. Party Politics. (20) 1: 16-36. doi. org/10.1177/1354068811436042

Charron, Nicholas, Bågenholm, Andreas. 2016. Ideology, party systems and corruption voting in European democracies. Electoral Studies. (41) 1: 3549. doi.org/10.1016/j.electstud. 2015. 11.022

Czesnik Mikolaj, Żerkowska-Balas, Marta, Kotnarowski, Michal. 2013. Voting as a habit in new democracies - Evidence from Poland. Communist and Post-Communist Studies. (46) 1: 95-107. Doi.10.1016/j.postcomstud. 2012.12.014

Čular, Goran. 2013. Političko predstavništvo u Hrvatskoj: predstoji li korjenita promjena stranačkog sustava? Političke analize. (4) 13: 3-11.

Čular, Goran, Gregurić, Ivan. 2007. How Cleavage Politics Survives despite
Everything: The Case of Croatia. Rad predstavljen na European Consortium of Political Research Joint Session of Workshops, Helsinki, 7-12. svibnja 2007.

Dolenec, Danijela. 2012. The Absent Socioeconomic Cleavage in Croatia: a Failure of Representative Democracy? Politička misao. (49) 5: 69-88.

Ecker, Alejandro, Glinitzer, Konstantin, Meyer, Thomas. 2016. Corruption Performance Voting and the Electoral Context. European Political Science Review. (8) 3: 333-354. DOI:10.1017/ S1755773915000053

Engler, Sarah. 2016. Corruption and Electoral Support for New Political Parties in Central and Eastern Europe. West European Politics. (39) 2: 278-304. Doi.org/10.1080/01402382. 2015.1084127

Ferić, Ivana. 2008. Sustav vrijednosti kao odrednica dominantnih političkih preferencija. Društvena istraživanja. (17) 4-5: 615-629.

Gallego, Aina. 2010. Understanding Unequal Turnout: Education and Voting in Comparative Perspective. Electoral Studies. (29) 2: 239-248. Doi. org/10.1016/j.electstud.2009.11.002

Glaurdić, Josip, Vuković, Vuk. 2016. Voting after war: Legacy of conflict and the economy as determinants of electoral support in Croatia. Electoral Studies. (42) 2: 135-145. Doi.org/ 10.1016/j.electstud.2016.02.0127

Goerres, Achim. 2007. Why are Older People More Likely to Vote? The Impact of Ageing on Electoral Turnout in Europe. British Journal of Political Research. (9) 1: 91-121. DOI: 10.1111/j.1467-856X.2006.00243.x

Grasso, Maria. 2014. Age, Period and Cohort Analysis in a Comparative Context: Political Generations and Political Participation Repertoires 
in Western Europe. Electoral Studies. (33) 1: 63-76. Doi.org/10.1016/j.electstud.2013.06.003

Grönlund, Kimmo, Setälä, Maija. 2007. Political Trust, Satisfaction and Voter Turnout. Comparative European Politics. (5) 4:400-422. DOI.10.1057/palgrave.cep.6110113

Hanley, Shaun, Sikk, Alan. 2016. Economy, corruption or floating voters? Explaining the breakthroughs of anti-establishment reform parties in Eastern Europe. Party Politics. (22) 4: 522 533. DOI:10.1177/1354068814550438

Haughton, Tim, Deegan-Krause, Kevin. 2015. Hurricane Season: Systems of Instability in Central and East European Party Politics. East European Politics and Societies. (29) 1: 61-80. DOI:10.1177/0888325414566072

Henjak, Andrija. 2007. Values or interests: Economic Determinants of Voting Behaviour in the 2007 Croatian Parliamentary Elections. Politička misao. (44) 5: 71-90.

Henjak, Andrija, Zakošek, Nenad, Čular, Goran. 2013. Croatia. U: Bergund, Sten i dr. (ur). Handbook of Political Change in Eastern Europe. Chentelham: Edward Elgar, str. 443-480.

Hirschmann, Albert O. 2010, $1970 .^{1}$ Izlazak, glas, lojalnost. Reakcije na propadanje tvrtki, organizacija $i$ država. Zagreb: Fakultet političkih znanosti.

Jensen, Carsten, Jespersen, Bjarke Bøgeskov. 2017. To have or not to have: Effects of economic inequality on turnout in European democracies. Electoral Studies. (45) 1: 24-28. Doi. org/10.1016/j.electstud.2016.11.009

Jou, Willy. 2010. Continuities and changes in left-right orientations in new democracies: The cases of Croatia and Slovenia. Communist and Post-Communist Studies. (43) 1: 97-113. DOI: 10.1016/j.postcomstud.2010.01.007
Jung Dong-Joon. 2017. Irrationalizing the rational choice model of voting: The moderating effects of partisanship on turnout decisions in Western and postcommunist democracies. Electoral Studies. (50) 1: 26-38. Doi. org/10.1016/j.electstud.2017.09.005

Karp, Jeffrey, Banduci, Susan. 2008. Political Efficacy and Participation in Twenty-Seven Democracies: How Electoral Systems Shape Political Behaviour. British Journal of Political Science. (38) 2: 311-334. Doi. org/10.1017/S0007123408000161

Karp, Jeffrey, Brockington, David. 2005. Social Desirability and Response Validity: A Comparative Analysis of Overreporting Voter Turnout in Five Countries. The Journal of Politics. (67) 3: 825-840. DOI: $10.1111 / \mathrm{j} .1468-$ 2508.2005.00341.x

Kostadinova, Tatiana. 2003. Voter turnout dynamics in post-communist Europe. European Journal of Political Research. (42) 6: 741-759. DOI: 10.1111/1475-6765.00102

Kostadinova, Tatiana, Power, Timothy. 2007. Does Democratization Depress Participation? Voter Turnout in Latin America and Eastern European Transitional Democracies. Political Research Quarterly. (60) 3: 363-377. Doi. org/10.1177/1065912907304154

Lamza Posavec, Vesna. 2004. Apstinencija na izborima za Hrvatski sabor 2003. godine: tko i zašto nije glasao. Društvena istraživanja. (13) 3: 383404.

Larchinese, Valentino. 2007. Voting over Redistribution and the Siye of the Welfare State: The Role of Turnout. Political Studies. (55) 3: 568-585. DOI: 10.1111/j.1467-9248.2007.00658.x

Letki, Natalia. 2004. Socialization for Participation? Trust, Membership and Democratization in East-Central Eu- 
rope. Political Research Quarterly. (57) 4: 665-679.

Linek, Lukáš, Petrúšek, Ivan. 2016. What's past is prologue, or is it? Generational effects on voter turnout in post-communist countries, 1990-2013. Electoral Studies. (42) 2: 78-90. Doi.org/10.1016/j.electstud.2016.02.002

Mahler, Vincent, Jesuit, David, Paradowski, Piotr. 2015. Electoral Tunout and State Redistribution: A Cross-National Study of 14 Developed Country. Luxembourg Income Study Working Paper Series, br. 633.

Northmore-Ball, Ksenia. 2016. Increasingly Unequal Turnout in Eastern European New Democracies: Communist and Transitional Legacies Versus New Institutions. Electoral Studies. (42) 2: 188-200. Doi.org/10.1016/j. electstud.2016.01.012

O'Dwyer, Connor. 2014. What Accounts for Party System Stability? Comparing the Dimensions of Party Competition in Postcommunist Europe. Europe-Asia Studies. (66) 4: 511-535. doi. org/10.1080/09668136.2014.897430

Offe, Claus. 2013. Participatory Inequality in the Austerity State: A Supply Side Approach. U: Streeck, Wolfgang, Schäfer, Armin. (ur.). Politics in the Age of Austerity. Cambridge: Polity Press, str. 196-218.

Pacek, Alexander, Pop-Eleches, Grigore, Tucker, Joshua. 2009. Disenchanted or discerning: Voter turnout in post-communist countries. The Journal of Politics. (71) 2: 473-491. Doi. org/10.1017/S0022381609090409

Pop-Eleches, Grigore. 2010. Throwing Out the Bums: protest voting and anti-establishment parties after communism. World Politics. (62) 2: 221-260. DOI:10.1017/S0043887110000043

Roberts, Andrew. 2008. Hyperaccountability: Economic voting in Central and Eastern Europe. Electoral Studies. (27) 3: 533-546. DOI:10.1016/j.electstud.2008.01.008

Schäfer, Armin. 2013. Liberalism, Inequality in the Austerity State. U: Streeck, Wolfgang, Schäfer, Armin. (ur.). Politics in the Age of Austerity, Cambridge: Polity Press, str. 169-195.

Sikk, Alan. 2005. How unstable? Volatility and the genuinely new parties in Eastern Europe. European Journal of Political Research. (44) 3: 391-412. DOI:10.1111/j.1475-6765.2005.00232.x

Sikk, Alan. 2012. Newness as a winning formula for new political parties. Party Politics. (18) 4: 465-486. DOI: $10.1177 / 1354068810389631$.

Streeck, Wolfgang, Mertens, Danel. 2013. Public Finance and the Decline of State Capacity in Democratic Caputalism. U: Streeck, Wolfgang, Schäfer, Armin. (ur.). Politics in the Age of Austerity. Cambridge: Polity Press, str. 26-58.

Šiber, Ivan. 2003. Contemporary Political Orientations and Ideological Conflicts during WWII: The Significance of the Family Political Biography'. U: Stein, Kuhnle, Sokolović, Džemal. (ur.). The Balkans: Searching for Solutions. Bergen: Stein Rokkan Centre, str. 21-32.

Šiber, Ivan. 2001. Političko ponašanje u izborima 1990-2000. U: Kasapović, Mirjana. (ur). Hrvatska politika 19902000. Zagreb: Fakultet političkih znanosti, str. 65-99.

Šiber, Ivan. 1998. Povijesni i etnički rascjepi u hrvatskom društvu. U: Kasapović, Mirjana, Šiber, Ivan, Zakošek, Nenad. Birači i demokracija. Utjecaj ideoloških rascjepa na politički život. Zagreb: Alinea, str. 51-94.

Šiber, Ivan. 1997. Izborne orijentacije i ideologijski sukobi tijekom Drugoga svjetskog rata: značenje političke bio- 
grafije obitelji. Politička misao. (34) 2: 104-128.

Tavits, Margit. 2008. Party Systems in the Making: The Emergence and Success of New Parties in New Democracies. British Journal of Political Science. (38) 1: 113-133. DOI:10.1017/ S0007123408000069

Toka, Gabor. 2004. The Impact of Turnout on Election Outcomes in a Crossnational Perspective. Rad predstavljen na International Conference of Europeanists organized by the Council for European Studies, Chicago, 11-13. ožujka 2004.

Zakošek, Nenad, Čular, Goran. 2004. Croatia. U: Berglund, Sten i dr. (ur)
Handbook of Political Change in Eastern Europe. Cheltenham: Edward Elgar.

Zakošek, Nenad. 1998. Ideološki rascjepi i stranačke preferencije hrvatskih birača. U: Kasapović, Mirjana, Šiber, Ivan, Zakošek, Nenad. Birači i demokracija. Utjecaj ideoloških rascjepa na politički život. Zagreb: Alinea, str. 11-50.

Zakošek, Nenad. 2001. Struktura biračkog tijela i političke promjene $\mathrm{u}$ siječanjskim izborima 2000. U: Kasapović, Mirjana. (ur). Hrvatska politika 1990-2000. Izbori, stranke i parlament u Hrvatskoj. Zagreb: Fakultet političkih znanosti, str. 99-122.

\title{
Loyalty, Voice or Exit: Electoral Participation and Support for New Parties in Croatia
}

\begin{abstract}
The author analyses changes in electoral behaviour and electoral participation which took place in the 2015. and 2016. parliamentary elections in Croatia. In these elections both support for new parties and electoral abstention simultaneously reached their highest level so far. The author starts from the assumption that electorates of new parties and abstainers are very similar in their evaluations of political system and political elites' performance, but that they differ in perception of their ability to influence politics through electoral participation. At the same time, voters of old and new parties are similar with respect to perception of their ability to influence politics, but they differ in their identification with predominant ideological cleavages, and their attitudes toward political system and political elites. The author tests these propositions using data from electoral surveys conducted after the 2015. and 2016. elections. Results of the analysis support principal expectations of the paper about differences between voters of old and new parties and electoral abstainers.
\end{abstract}

Key words turnout, electoral behaviour, political cleavages, party competition, political efficacy 
